\title{
Children literature: What do they say?
}

\begin{abstract}
hildren literature consists of all creative and imaginative writing focusing on reading, leisure and evaluation by children. Basically children literature covers most quality books suitable for children. The objectives of this paper are to identify the interest of university students toward the research of children's literature and to list out the types of children story that arouse the interest of the students to research on. 30 postgraduate students from Universiti Putra Malaysia studied the children literature in a group. They have formed six groups and each group has five members. The findings were analysed by using the qualitative approach. The students were given a set of questionnaires. It is found that the students were interested to research on children literature and they have a list of perceptions, assumptions and views towards children literature.
\end{abstract}

Keyword: Children literature, perception 